\title{
PENGEMBANGAN MEDIA PEMBELAJARAN INTERAKTIF PADA PEMBELAJARAN EKONOMI
}

\author{
Darmawaty Tarigan ${ }^{1}$ dan Sahat Siagian ${ }^{2}$ \\ SMAN 12 Medan $^{1}$ dan Universitas Negeri Medan ${ }^{2}$ \\ darmawatytarigan@yahoo.com ${ }^{1}$ dan Sahat.sgn61@gmail.com²
}

\begin{abstract}
Abstrak: Penelitian ini bertujuan untuk: (1) menghasilkan media pembelajaran interaktif yang layak digunakan, mudah dipelajari pebelajar dan dapat dipakai untuk pembelajaran individual, (2) untuk mengetahui keefektifan media pembelajaran interaktif yang dikembangkan pada pembelajaran Ekonomi. Jenis penelitian ini adalah penelitian dan pengembangan menggunakan model Borg dan Gall yang dipadu dengan model Dick dan Carey. Hasil penelitian menunjukkan; (1) uji ahli materi pelajaran Ekonomi berada pada kualifikasi sangat baik (88,12\%), (2) uji ahli desain pembelajaran berada pada kualifikasi sangat baik (83,5\%), (3) uji ahli rekayasa perangkat lunak berada pada kualifikasi sangat baik (86,07\%), (4) uji coba perorangan berada pada kualifikasi sangat baik (88,57\%), uji coba kelompok kecil berada pada kualifikasi sangat baik (96,27\%), uji coba lapangan berada pada kualifikasi sangat baik (98,46\%). Hasil penelitian menunjukkan bahwa terdapat perbedaan yang signifikan antara hasil belajar siswa yang dibelajarkan dengan menggunakan media pembelajaran interaktif dengan media pembelajaran power point, diperoleh thitung $=4,25$ pada taraf signifikansi $\alpha=0,05$ dengan dk 96 diperoleh $t_{\text {tabel }}=$ 1,67 sehingga thitung $>t_{\text {tabel }}$. Disimpulkan bahwa, hasil belajar kelompok siswa yang dibelajarkan dengan menggunakan media pembelajaran interaktif sebesar 84,83\% lebih tinggi dari kelompok siswa yang dibelajarkan dengan menggunakan media pembelajaran power point sebesar 75,2\%.
\end{abstract}

Kata Kunci: pengembangan media, pembelajaran interaktif, pembelajaran ekonomi

Abstract: This study aims to: (1) generate media interactive learning proper use, easy to learn learners and can be used for individual learning, (2) to determine the effectiveness of interactive learning media developed in the learning economy. This research is a research and development using the Borg and Gall models are combined with models of Dick and Carey. The results showed; (1) test the Economic subject matter experts are at a very good qualifying $(88.12 \%)$, (2) test the instructional design experts are in excellent qualifications (83.5\%), (3) test software engineering experts are in qualifying very good (86.07\%), (4) individual testing are at a very good qualifying $(88.57 \%)$, small group trial is at a very good qualifying $(96.27 \%)$, field trials are in qualifying so good $(98.46 \%)$. The results showed that there are significant differences between student learning outcomes that learned to use the media interactive learning with instructional media power point, obtained $t=4.25$ at significance level $\alpha=0.05$ with $96 d f=1,67$ thus obtained ttabel thitung > ttabel. It was concluded that, the learning outcomes of students groups that learned to use interactive learning media by $84.83 \%$ higher than the group of students that learned by using learning media power point $75.2 \%$.

Keywords: media development, interactive learning, learning economy

\section{PENDAHULUAN}

Ketersediaan media yang biasa digunakan di sekolah seperti buku teks,majalah,surat kabar dan papan tulis yang menimbulkan kebosanan dalam melakukan pembelajaran dalam kelas. Sedangkan media audio dan visual seperti : Televisi, Radio, dan Video sedangkan media elektronik seperti komputer. Semua media yang digunakan tersebut belum dimanfaatkan dengan maksimal bahkan komputer hanya sebagai "penghias sekolah saja" karena tidak dipergunakan dengan maksimal. Oleh sebab itu, perlu adanya kreativitas pendidik dalam memanfaatkan media, bahkan sering dijumpai pendidik yang memanfaatkan media pembelajaran dengan memanfaatkan media pembelajaran apa yang ada di sekolah, misalnya buku teks saja. Para guru tidak mampu menciptakan media 
pembelajaran yang menarik perhatian siswa dalam menyimak materi pelajaran.

Reigeluth (1983: 20) menyatakan bahwa hasil belajar secara umum dapat dikategorikan menjadi 3 indikator, yakni 1) efektivitas pembelajaran yang biasanya diukur dari tingkat keberhasilan ( prestasi ) siswa dari berbagai sudut, 2) efisien pembelajaran yang biasanya diukur dari waktu belajar atau biaya pembelajaran, dan 3) daya tarik pembelajaran yang biasanya diukur dari tendensi siswa ingin belajar secara terus menerus. Pada pembelajaran di SMAN 12 Medan tingkat keberhasilan terhadap pembelajaran masih belum maksimal. Sehingga sangat diperlukan adanya daya tarik dalam kegiatan pembelajaran yakni adanya pengembangan media pembelajaran akan menciptakan yang menarik siswa untuk belajar

$$
\text { Menurut Arsyad (2002:54), }
$$

pembelajaran dengan komputer dapat merangsang siswa untuk mengerjakan berbagai latihan dikarenakan tersedianya berbagai animasi, ilustrasi grafik, dan warna yang menambah realisme. Komputer juga dapat mengakomodasikan siswa yang lamban menerima pelajaran karena ia dapat memberikan iklim yang lebih afektif dengan cara yang lebih individual dan tidak membosankan. Selain itu, pemanfaatan komputer dapat memberikan umpan balik atau

Pembelajaran merupakan sebuah upaya yang dilakukan untuk memperoleh kompetensi pengetahuan, keterampilan, dan sikap yang diperlukan dalam melakukan suatu pekerjaan. Miarso (2009: 144) memaknai istilah pembelajaran sebagai aktivitas atau kegiatan yang berfokus pada kondisi dan kepentingan pemelajar (learner centered). Istilah pembelajaran digunakan untuk menggantikan istilah "pengajaran" yang lebih bersifat sebagai aktivitas yang berfokus pada guru (tecaher centered). Pembelajaran adalah proses yang sengaja dirancang untuk menciptakan terjadinya aktivitas belajar dalam diri individu. Dengan kata lain, pembelajaran merupakan sesuatu hal yang sengaja dirancang untuk mendukung terjadinya proses belajar internal dalam diri individu.

Seiring dengan pendapat di atas, Surya (2003:7) menyatakan bahwa: Pembelajaran ialah suatu proses yang dilakukan oleh individu untuk memperoleh suatu perubahan perilaku yang baru secara keseluruhan, sebagai hasil dari pengalaman individu itu sendiri dalam interaksi dengan lingkungannya. Pendapat lainnya Rusman,dkk (2003:16) mengatakan bahwa pembelajaran merupakan proses interaksi komunikasi antara sumber belajar, guru dan siswa.

Menurut Sadiman (2011:6) memaknai pembelajaran sebagai kegiatan yang menekankan pada proses balajar maka usahausaha yang terencana dalam memanipulasi sumber-sumber belajara agar terjadi proses belajar dalam diri siswa

Sagala (2011:61) mengatakan bahwa pembelajaran merupakan kombinasi dalam suatu pembelajaran antara siswa dengan guru dan tenaga lainnya. Kombinasi itu misalnya tenaga laboratorium, buku-buku, papan tulis kapur, fotografi, slide, film, audio dan video tape. Unsur fasilitas dan perlengkapan terdiri dari ruang kelas, perlengkapan audio visual, juga komputer, dan yang terakhir adalah prosedur yang meliputi jadwal, dan metode penyampaian informasi, praktek belajar, ujian dan sebagainya.

Sedangkan Case (2002:2) mengatakan ilmu ekonomi adalah suatu studi tentang bagaimana individu dan masyarakat menentukan pilihan penggunaan sumber daya yang langka yang telah disediakan oleh alam dan generasi sebelumnya. Sejalan dengan itu, Mankiw (2013:4) mengemukakan bahwa ilmu ekonomi adalah ilmu yang mempelajari bagaimana masyarakat mengelola sumber daya mereka yang terbatas. Soeharno (2006:1) mengemukakan ilmu ekonomi sebagai ilmu sosial yang mempelajari perilaku manusia dalam usahanya untuk memenuhi kebutuhannya.

Kata media didefinisikan dengan multi makna baik dilihat secara terbatas maupun secara luas. Munculnya berbagai macam definisi disebabkan adanya perbedaan dalam sudut pandang, maksud, dan tujuannya.Heinich (1996:5) Media merupakan komunikasi berarti seperti film, televisi, radio, audio, rekaman, foto, diproyeksikan dan sejenisnya adalah media komunikasi. Semuanya itu dianggap media pembelajaran ketika digunakan untuk menyampaikan pesan dalam pembelajaran

AECT (Association forEducation and Communication Technology , 1977:201) memaknai media sebagai segala bentuk yang dimanfaatkan dalam proses penyaluran informasi. NEA(National Education Association) memaknai media sebagai segala benda yang dapat dimanipulasi, dilihat, 
didengar, dibaca, atau dibincangkan beserta instrumen yang digunakan untuk kegiatan tersebut.

Sadiman, dkk (2003:6) mengemukakan pendapat tentang media adalah Berbagai jenis komponen dalam lingkungan, siswa yang dapat merangsangnya untuk belajar Menurut Smaldino (2008:7) juga mengemukakan lima tipe dasar media, yaitu (1) teks, yang dapat disajikan dalam berbagai format seperti buku,poster, papan tulis, layar komputer, dan sebagainya, (2) audio, termasuk di dalamnya segala sesuatu yang dapat didengar seperti suara manusia, musik, (suara deru mesin),suara berisik, dan sebagainya, (3) visual, termasuk diagram dalam poster, gambar di papan tulis, foto,grafik di buku, kartun, dan sebagainya, (4) Video, yaitu media yang menampilkan gerakan termasuk DVD, rekaman video, animasi komputer, dan sebagainya (5) perekayasa, yaitu bersifat tiga dimensi dan bisa disentuh dan dipegang oleh siswa (6) Orang-orang, berupa guru, siswa dan ahli bidang studi

Dalam merencanakan

dan melaksanakan aktivitas pembelajaran, setiap guru dituntut dapat mempersiapkan dan memfungsikan segala unsur yang menunjang kelancaran proses pembelajaran agar dapat berjalan dengan efektif dan efisien.Sebagai salah satu unsur dalam menunjang pembelajaran, guru dituntut agar rmengetahui dan merancang pemakaian media pembelajaran serta dapat mengetahui fungsi dan kegunaan media tersebut. Menurut Sadiman (2003:17) fungsi atau kegunaan media antara lain: (1) memperjelas penyajian pesan agar tidak terlalu bersifat vervalistik, (2) mengatasi keterbatasan ruang waktu dan daya indra, (3) dapat mengatasi sikap pasif pada anak, (4) dengan sifat yang unik pada setiap siswa ditambah lagi dengan lingkungan dan pengalaman yang berbeda dapat diatasi dengan media

Berdasarkan keahlian pengguna media, media dapat dikelompokkan atas (1)media yang tidak memerlukan keahlian khusus misalnya: papan tulis/ white board,transparansi (OHP), bahan cetak (buku, modul, handout), dan (2) media yangmemerlukan keahlian khusus yaitu: program audio visual, program slide, Microsoft Powerpoint dan program internet. Berdasarkan perlu tidaknya guru atau tutor dalam penggunaannya, media dapat dikelompokkan atas (1) yang tergantung hadimya guru misalnya papan tulis/white board, transparansi (OHP), dan (2) media yang tidak bergantung kehadiran guru misalnya media rekam bahan belajar mandiri (dapat dipelajari tanpa guru/ pengajar).

Media pembelajaran merupakan bagian yang saling terikat dengan metode,Strategi dalam sistem pembelajaran. Hal ini sependapat oleh Sumiati (2008:159-160) mengatakan bahwa media pembelajaran merupakan bagian integral dalam sistem pembelajaran yang dapat digunakan untuk menyalurkan pesan (message), merangsang pikiran, perasaan, perhatian dan kemauan siswa sehingga terdorong proses belajar Sejalan dengan itu Hamid (2009:55) mengemukakan bahwa media pembelajaran adalah komponen strategi penyampaian yang dapat dimuati pesan yang akan disampaikan kepada pebelajar, apakah itu orang, alat atau bahan. Menurut Dengeng (dalam Weda,2013:9) menyebutkan media pembelajaran adalah komponen penyampaian strategi penyampaian yang dapat dimuati pesan yang disampaikan kepada siswa, baik berupa orang, alat ataupun bahan.

Ada dua pendekatan yang dilakukan dalam pemanfaatan rnedia pembelajaran menurut Sumiati (2008:162) yaitu : (1)media by design yaitu media pembelajaran yang dirancang, dipersiapkan, dan dibuat sendiri oleh guru lalu digunakan dalam proses pembelajaran, Pendekatan ini sudah tentu membutuhkan banyak biaya untuk membelinya, lagi pula belum tentu media itu cocok untuk penyampaian bahan pelajaran dan dengan kegiatan belajaryang dilakukan siswa (2)media by utulization yaitu media pembelajaran yang dibuat oleh orang lain atau suatu lembaga/instritusi, sedangkan guru hanya tinggal menggunakan atau memanfaatkannya

Rudi Brets (dalam Sumiati, 2008:162) mengklasifikasikan media menjadi 3 ciri yaitu suara (audio), bentuk (visual) dan gerak (motion). Sehingga dapat dikatakan bahwa dalam media pembelajaran yang baik harus memiliki salah satu dari ketiga karakteristik media pembelajaran.

Penggunaan media pembelajaran pada tahap orientasi pembelajaran sangat

membantu keefeklifitasan proses pembelajaran dan penyampaian pesan isipembelajaran pada saat ini. Di samping membangkitkan motivasi dan minat siswa, media pembelajaran juga dapat membantu siswa meningkatkan pemahaman,penyajian data dengan menarik dan terpercaya, memudahkan penafsinan data, dan pemadatan informasi. Sejalan menurut Sumiati ( 2003:163) mengemukakan manfaat dari 
penggunaan media pembelajaran di sekolah yaitu : (1) Menjelaskan materi pembelajaran objek yang abstrak (tidak nyata) menjadi konkrit (nyata), (2) memberikan pengalaman langsung karena siswa dapat berkomunikasi dan berinteraksi dengan lingkungan tempat belajarnya, (3) Mempelajari materi pembelajaran secara berulang-ulang, (4) memungkinkan adanya persamaan pendapat dan persepsi yang benar terhadap suatu materi pembelajaran atau objek,(4) menarik perhatian siswa, (5) Membantu siswa belajar secara individual, kelompok dan klasikal, (6) materi pembelajaran lebih lama diingat dan mudah untuk diungkapkan kembali dengan cepat dan tepat, (7) mempermudah dan mempercepat guru menyajikan materi pembelajaran dalam proses pembelajaran, sehingga memudahkan siswa untuk mengeti dan memahami, (8) mengatasi keterbatasan ruan, waktu dan indra.

Media interaktif digolongkan sebagai media konstruktifistik yang terdiri dari pembelajaran, siswa, dan proses pernbelajaran. Dalam proses pembelajaran teknologi seperti komputer, adalah alat dalam multimedia dan jaringan web terluas di dunia yang sangat besar pengaruhnya terhadap siswa dalam proses pembelajaran. Program multimedia interaksi merupakan salah satu media pembelajaran yang berbasis komputer yang mensinergikan semua media yang terdiri dari teks, grafik, foto, video, animasi, musik, narasi menurut Warsita (2008:36)

Pengertian interaktif menurut Warsita (2008:156) terkait dengan komunikasi dua arah. Komponen komunikasi dalam multimedia interaktif (berbasis komputer) adalah hubungan antara manusia (sebagaiuser/pengguna produk) dan komputer (software/ aplikasi/produk dalam format filetertentu biasanya dalam bentuk CD). Dengan demikian produk/CD/aplikasi yang diharapkan memiliki hubungan dua arah/ timbal balik antara software/ aplikasi dengan usernya. Interaktifitas dalam multimedia diberikan batasan sebagai berikut (1) pengguna (user) dilibatkan untuk berinteraksi dengan program aplikasi, (2) aplikasi informasi interaktif bertujuan agar pengguna bisa mendapatkan hanya informasi yang diinginkan saja tanpa harus melahap semuanya.

Menurut Cheng (2009:204)

mengatakan bahwa multimedia interaktif dirancang untuk menawarkan untuk pembelajaran yang interaktif dalam bentuk 3D, grafik, suara, video, animasi dan menciptakan interaksi. Sedangkan menurut Heinich (1997:187) mengemukakan kumpulan materi pembelajaran yang menyertakan lebih dari satu jenis media yang disusun dalam satu topik yang di dalamnya terdapat film strip, slide, videotape, rekaman, gambar, OHP, film pendek, peta, lembar kerja, grafik, bagan, brosur, objek nyata dan model.

Karakteristik terpenting pada media pembelajaran interaktif adalah bahwa siswa tidak hanya memperhatikan penyajian atau objek, tetapi dipaksa untuk berinteraksi selama mengikuti pelajaran. Menurut Miarso (2009:465) paling sedikit ada tiga macam interaksi yang dapat diidentifikasi. Pada tingkat pertama siswa dengan sebuah program, misalnya mengisi blanko pada teks yang terprogram. Tingkat berikutnya siswa berinteraksi dengan mesin, misalnya mesin pembelajaran, simulator, laboratorium bahasa atau terminal komputer. Bentuk ketiga media interaktif adalah yang mengatur interaksi antar siswa secara teratur tetapi tidak terprogram.

Macromedia flash merupakan software yang sudah lazim di gunakan di segala bidang, terutama dalam pendidikan. Macromedia flash mampu berfungsi sebagai media presentasi informasi dalam bentuk teks,grafik, simulasi, animasi dan latihan-latihan, analisis kuantitatif dan umpan balik langsung menurut Viajayani (2013:146) sejalan dengan itu Arum (2012: 1) juga mengemukan bahwa Macromedia flash merupakan software yang digunakan dalam membuat animasi interaktif.

Macromedia Flash merupakan software yang dipakai oleh para profesional web dalam menampilkan multimedia menggabungkan unsur teks, grafis, animasi, suara serta ineraktivitas penggunanya (Rahman, 2008:5). Animasi hasil dan Macromedia Flash dapat diubah ke dalam format lain yakni dalam bentuk swf dan flash player flash dengan menggunakan bahasa pemrogramman ActionScript Animasi yang dihasilkan Flash adalah animasi berupa file movie. Movie yang dihasilkan dapat berupa grafik atau teks. Selain itu, Flash juga memiliki kemampuan untuk mengimpor file suara, video maupun file gambar dari aplikasi lain. Macromedia Flash merupakan program animasi web yang diproduksi oleh Macromedia corp, yaitu sebuah vendor software yang bergerak di bidang animasi web

Sutopo (2002:2) mengemukakan macromedia flash adalah perangkat lunak 
aplikasi untuk pembuatan animasi yang digunakan pada web. Macromedia flash mampu melengkapi situs web dengan beberapa macam animasi, suara, animasi interaktif, dan lain-lain. Macromedia flash adalah program grafis yang diperuntukan untuk motion atau gerak dan dilengkapi dengan script untuk programming (action script) dengan program ini memungkinkan pembuatan animasi media interaktif, game. Macromedia Flash adalah salah satu dari authoring tool untuk produksi multimedia dan internet. Flash tidak hanya menggabungkan elemen multimedia ke dalam portable movie, tetapi di samping itu dengan ActionScript, Flash mempunyai kemampuan dalam membuat interactive scripting.

Menurut Zaman, dkk ( 2012:3) mengemukakan bahwa karakteristik media pembelajaran interaktif adalah :1) curriculum,desain pembelajaran harus sesuai dengan kurikulum pendidikan yang sudah ditetapkan. Aspek desain kurikulum dan pembelajaran terdiri dari 6 penilaian yaitu (1) kesesuaian sasaran, (2) kelengkapan unsur pembelajaran,(3) kejelasan tujuan, (4) konsistensi tujuan-materi-evaluasi,(5) pemberian contoh dan (6) aspek-aspek pedagogik. 2) content, penilaian content pada media interaktif didasarkan beberapa aspek, yakni (1) kebenaran substansi materi, (2) kecukupan cakupan , (3) kedalam, (4) aktualitas, (5)kelengkapan sumber. 3) communication, (1) aspek kejelasan pesan,menumbuhkan motivasi 4) computer capasity, kemampuan komputer multimedia 5) creativity, tidak melanggar etika 6) compability, dapat diterima secara umum, dan mudah digunakan 7) cosmetic, tampilan desain yang menarik dan 8) interaktivity memunculkan produk yang interaktif

Masalah dalam penelitian ini adalah: (1) Apakah Media pembelajaran interaktif yang dikembangakan pada pembelajaran ekonomi layak untuk digunakan?; dan (2) Apakah Penggunaan media pembelajaran interaktif lebih efektif dibanding dengan power point pada pembelajaran ekonomi?

\section{METODE}

Penelitian dilakukan di SMA Negeri 12 Medan yang terletak di Jalan Cempaka No 7 Helvetia Medan pada siswa kelas X semester ganjil. Model pengernbangan yang digunakan dalam media pembelajaran interaktif ini adalah model pengernbangan Borg and Gall yang dikombinasikan dengan model pengembangan pembelajaran model Dick dan Carey (2005). Adapun langkah-langkah tahapan pengembangannya adalah sebagai berikut :

1. Melakukan penelitian pendahuluan yang meliputi:

a. Identifikasi kebutuhan pembelajaran dan menentukan standar kompetensi mata pelajaran.

b. Melakukan analisis pembelajaran.

c. Mangidentifikasi karakteristik dan perilaku awal siswa.

d. Menulis kompetensi dasar dan indikatornya.

e. Menulis tes acuan patokan.

f. Menyusun strategi pembelajaran yang terdiri dari:
a) Penjelasan tentang tujuan instruksional
b) Penjelasan relevansi isi pelajaran baru
c) Penjelasan tentang materi pelajaran atau konsep, prinsip, dan prosedur yang akan dipelajari siswa
d) Tes formatif dan umpan balik
e) Tindak lanjut

g. Mengembangkan bahan pembelajaran.

2. Pembuatan desain sofiware, yang meliputi

a. Pembuatan naskah

b. Pembuatan storyboard

c. Pembuatan Flowchart View

3. Pengumpulan bahan, yang meliputi:

a. Pembuatan dan pengumpulan gambar (image) dan animasi.

b. Perekaman dan pengumpulan audio

4. Mengembangkan dan membuat media pembelajaran interaktif

5. Review dan uji coba produk.

6. Uji keefektifan produk

\section{Tahap Uji Coba Produk \\ 1) Desain Uji Coba}

Penelitian pengembangan akan melakukan desain uji coba untuk menguji validasi terhadap ahli yang berkompetensi dalam melakukan validasi. Tahap-tahapnya adalah sebagai berikut:

a. Validasi ahli materi Ekonomi

b. Validasi ahli perangkat lunak

c. Validasi ahli desain instruksional

d. Analisis konseptual 
e. Revisi pengembangan (tahap I), berdasarkan penilaian yang berupa masukan, kritik atau saran dari 2 ahli materi, 2 ahli perangkat lunak dan 2 ahli desain instruksional untuk dilakukan perbaikan.

f. Uji coba satu-satu/perorangan

g. Analisis konseptual

h. Revisi pengembangan (tahap II), berdasarkan penilaian yang berupa masukan, kritik atau saran dari 3 siswa kelas $\mathrm{X}$ yang memiliki prestasi tinggi, sedang dan rendah.

i. Uji coba kelompok kecil. Penilaian terhadap program ini berdasarkan angket yang telah diisi oleh 9 siswa kelas $\mathrm{X}$

j. Analisis konseptual dan produk

k. Revisi produk (tahap III)

1. Uji coba lapangan terhadap 46 siswa kelas $\mathrm{X}-3$

m. Penilaian mengenai daya tarik dan kelayakan produk

n. Analisis empirik (tahap IV)

o. Revisi kecil

p. Uji keefektifitas produk

Subyek uji coba Produk pengembangan media pembelajaran interaktif memerlukan balikan-balikan dalam rangka evaluasi formatif. Balikan-balikan tersebut diperoleh dari para subjek yang terdiri dari 2 orang ahli desain pembelajaran, 2orang ahli materi, 2 orang ahli perangkat lunak, dan pemakai produk yaitu siswa terdiri dari 3 orang siswa kelas $\mathrm{X}$ untuk uji coba satu-satu, 9 orang siswa kelas $X$ untuk uji coba kelompok kecil dan 46 siswa kelas X untuk uji coba lapangan.

Teknik Analisis data dalam penelitian ini menggunakan analisis deskriptif kuantitatif.. Data kualitatif yang berupa pernyataan sangat kurang baik, kurang baik, sedang, baik dan sangat baik diubah menjadi data kuantitatif dengan skala nilai 1 sampai 5. Hasilnya diratarata dan digunakan untuk menilai kualitas software pembelajaran. Kriteria software akan dikonversikan menjadi nilai dengan skala lima menggunakan Skala Likert yang dianalisis secara deskriptif persentase dengan rumus sebagai berikut (Purwanto, 2009:112)

$X=\frac{R}{N} \times 100 \%$

Dimana : $\mathrm{S}$ : Nilai yang diharapkan (Dicari)
$\mathrm{R}$ : Jumlah skor dari item atau soal yang dijawab benar

$\mathrm{N}$ : Skor maksimum dari tes

tersebut

Dengan kriteria penilaian seperti yang tertulis pada Tabel 1 berikut ini.

Tabel 1. Kriteria penilaian

\begin{tabular}{|c|l|c|}
\hline Nilai & \multicolumn{1}{|c|}{ Kriteria } & Persentase \\
\hline A & Sangat baik & $81 \% \leq X \leq 100 \%$ \\
\hline B & Baik & $61 \% \leq X<80 \%$ \\
\hline C & Sedang & $41 \% \leq X<60 \%$ \\
\hline D & Kurang baik & $21 \% \leq X<40 \%$ \\
\hline E & $\begin{array}{l}\text { Sangat kurang } \\
\text { baik }\end{array}$ & $0 \% \leq X<20 \%$ \\
\hline
\end{tabular}

$\mathrm{X}=$ Skor Empiris (Purwanto, 2009:82)

Analisis data pada penelitian ini menggunakan tehnik analisis kuantitatif. Sebelum dilakukan uji hipotesis, terlebih dahulu dilakukan uji persyaratan yaitu uji normalitas dan uji homogenitas. Uji normalitas dilakukan untuk mengetahui apakah skor variabel yang diteliti berasal dari populasi yang berdistribusi normal. Gejala yang diamati berdistribusi normal jika $\mathrm{L}_{\text {hitung }}<\mathrm{L}_{\text {tabel, }}$ pada signifikasi 0,05 . Untuk menguji homogenitas data, digunakan uji kesamaan dua varians.

Dilakukan uji dua pihak dengan taraf signifikansi 0,05 , hipotesis diatas diuji dengan statistika:

$\mathrm{F}=\frac{\text { Varians terbesar }}{\text { Varians terkecil }}$

(Sugiyono, 2008:199)

Kriteris pengujian hipotesis:

$\mathrm{H}_{0}$ diterima jika $\mathrm{F} \leq \mathrm{F}(\mathrm{V} 1, \mathrm{~V} 2)$ dan $\mathrm{H}_{0}$ ditolak jika $\mathrm{F} \geq \mathrm{F}(\mathrm{V} 1, \mathrm{~V} 2)$

Untuk melihat apakah ada perbedaan yang signifikan antara hasil belajar dengan penggunaan media pembelajaran interaktif dan Power point maka dilakukan uji hipotesis dengan uji t. Untuk melihat keefektifan media pembelajaran interaktif yang dieksperimenkan digunakan rumus perhitungan efektifitas berikut (Purwanto; 2004:112):

$X=\frac{R}{N} \times 100 \%$ 
Dimana :

$\mathrm{X}$ : Nilai yang diharapkan (Dicari)

$\mathrm{R}$ : Jumlah skor dari item atau soal yang dijawab benar

$\mathrm{N}$ : Skor maksimum dari tes tersebut

Adapun rumusan hipotesis statistik ini dinyatakan sbb :

Hipotesis : $\mathrm{H}_{0}: \mu 1=\mu 2$

$$
\mathrm{H}_{\mathrm{a}}: \mu 1>\mu 2
$$

Keterangan :

$\mu 1$ : Rata-rata hasil belajar ekonomi siswa yang diajar dengan menggunakan media pembelajaran interaktif

$\mu 2$ : Rata-rata hasil belajar ekonomi siswa yang diajar dengan menggunakan media pembelajaran power point

\section{HASIL DAN PEMBAHASAN \\ Hasil}

Berdasarkan indikator penilaian produk yang dikembangkan terhadap beberapa ahli menunjukkan bahwa:

\section{Hasil}

Tabel 2. Penilaian Para Ahli bidang Materi, Desain Pembelajaran, dan Media Pembelajaran

\begin{tabular}{|c|c|c|c|c|}
\hline No & Penilaian Para Ahli & $\begin{array}{c}\text { Jumlah } \\
\text { Skor }\end{array}$ & $\begin{array}{l}\text { Rata- } \\
\text { Rata \% }\end{array}$ & Kriteria \\
\hline 1 & $\begin{array}{l}\text { Penilaian Media Pembelajaran Interaktif Oleh Ahli Materi } \\
\text { Tentang Kualitas Materi Pembelajaran }\end{array}$ & 9,87 & 90,87 & $\begin{array}{l}\text { Sangat } \\
\text { Baik }\end{array}$ \\
\hline 2 & $\begin{array}{l}\text { Penilaian Media Pembelajaran Interaktif Oleh Ahli Materi } \\
\text { Tentang Kualitas Strategi Pembelajaran }\end{array}$ & $86 \%$ & 86,00 & $\begin{array}{c}\text { Sangat } \\
\text { Baik }\end{array}$ \\
\hline 3 & $\begin{array}{l}\text { Penilaian Media Pembelajaran Interaktif Oleh Ahli Materi } \\
\text { Tentang Sistem Penyampaian Pembelajaran }\end{array}$ & 8,75 & 87,50 & $\begin{array}{c}\text { Sangat } \\
\text { Baik }\end{array}$ \\
\hline 4 & $\begin{array}{l}\text { Penilaian Media Pembelajaran Interaktif Oleh Ahli Desain } \\
\text { Pembelajaran Tentang Aspek Kualitas Desain Pembelajaran }\end{array}$ & 87,5 & 87,5 & $\begin{array}{c}\text { Sangat } \\
\text { Baik }\end{array}$ \\
\hline 5 & $\begin{array}{l}\text { Penilaian Media Pembelajaran Interaktif Oleh Ahli Desain } \\
\text { Pembelajaran Tentang Aspek Kualitas Desain Informasi }\end{array}$ & 8,25 & 82,5 & Baik \\
\hline 6 & $\begin{array}{l}\text { Penilaian Media Pembelajaran Interaktif Oleh Ahli Desain } \\
\text { Pembelajaran Tentang Aspek Kualitas Desain Interaksi }\end{array}$ & 7,75 & 77,5 & Cukup \\
\hline 7 & $\begin{array}{l}\text { Penilaian Media Pembelajaran Interaktif Oleh Ahli Desain } \\
\text { Pembelajaran Tentang Aspek Kualitas Presentasi }\end{array}$ & 8,71 & 87,1 & $\begin{array}{l}\text { Sangat } \\
\text { Baik }\end{array}$ \\
\hline 8 & $\begin{array}{l}\text { Penilaian Terhadap Media Pembelajaran Interaktif pada } \\
\text { Pembelajaran Ekonomi Oleh Ahli Desain Pembelajaran }\end{array}$ & 8,36 & 83,65 & $\begin{array}{c}\text { Sangat } \\
\text { Baik }\end{array}$ \\
\hline 9 & $\begin{array}{l}\text { Penilaian Media Pembelajaran Interaktif Oleh Ahli Rekayasa } \\
\text { Perangkat Lunak Pada Aspek Pemprograman }\end{array}$ & 8,5 & 85,00 & $\begin{array}{c}\text { Sangat } \\
\text { Baik }\end{array}$ \\
\hline 10 & $\begin{array}{l}\text { Penilaian Media Pembelajaran Interaktif Oleh Ahli Rekayasa } \\
\text { Perangkat Lunak Pada Aspek Kualitas Teknis/Tampilan }\end{array}$ & 87,14 & 87,14 & $\begin{array}{c}\text { Sangat } \\
\text { Baik }\end{array}$ \\
\hline
\end{tabular}

Hasil uji coba berupa skor penilaian terhadap media pembelajaran interaktif pada pembelajaran Ekonomi pada uji coba perorangan dapat dilihat pada tabel 3 berikut :

Tabel 3. Skor Penilaian Media Pembelajaran Interaktif pada Pembelajaran Ekonomi Pada Uji Coba Perorangan Tentang Kualitas Materi Pembelajaran

\begin{tabular}{|c|c|c|c|c|c|c|c|}
\hline \multirow[b]{2}{*}{ No } & \multirow{2}{*}{ Indikator Penilaian } & \multicolumn{3}{|c|}{ Responden } & \multirow{2}{*}{$\begin{array}{l}\text { Jumlah } \\
\text { Skor }\end{array}$} & \multirow{2}{*}{$\begin{array}{l}\text { Rata- } \\
\text { rata }\end{array}$} & \multirow{2}{*}{ Kriteria } \\
\hline & & 1 & 2 & 3 & & & \\
\hline 1 & Kesesuaian materi & 4 & 4 & 5 & 13 & $86,67 \%$ & Sangat Baik \\
\hline 2 & Kejelasan petunjuk belajar & 4 & 4 & 4 & 12 & $80,00 \%$ & Baik \\
\hline
\end{tabular}




\begin{tabular}{|l|l|l|l|l|l|l|l|}
3 & $\begin{array}{l}\text { Kemudahan memahami } \\
\text { kalimat pada teks }\end{array}$ & 5 & 4 & 5 & 14 & $93,33 \%$ & Sangat Baik \\
\hline 4 & $\begin{array}{l}\text { Kemudahan memahami } \\
\text { pembelajaran }\end{array}$ & 4 & 4 & 5 & 13 & $86,67 \%$ & Sangat Baik \\
\hline 5 & Ketepatan urutan penyajian & 4 & 4 & 4 & 12 & $80,00 \%$ & Baik \\
\hline 6 & Kecukupan latihan & 4 & 5 & 4 & 13 & $86,67 \%$ & Sangat Baik \\
\hline 7 & Kejelasan umpan balik & 5 & 4 & 5 & 14 & $93,33 \%$ & Sangat Baik \\
\hline 8 & $\begin{array}{l}\text { Bantuan belajar dengan } \\
\text { program }\end{array}$ & 4 & 4 & 5 & 13 & $86,67 \%$ & Sangat Baik \\
\hline & Rata-rata & 85 & 8,25 & 9,25 & 86,67 & $86,67 \%$ & Sangat Baik \\
\hline
\end{tabular}

Penilaian siswa pada media pembelajaran interaktif tentang aspek kualitas teknis/tampilan dapat dilihat pada tabel 4 berikut.

Tabel 4. Skor Penilaian Media Pembelajaran Interaktif pada Pembelajaran Ekonomi Pada Uji Coba Perorangan Aspek Kualitas Teknis/Tampilan

\begin{tabular}{|c|c|c|c|c|c|c|c|}
\hline \multirow[b]{2}{*}{ No } & \multirow{2}{*}{ Indikator Penilaian } & \multicolumn{3}{|c|}{ Responden } & \multirow{2}{*}{$\begin{array}{l}\text { Jumla } \\
\text { h Skor }\end{array}$} & \multirow{2}{*}{ Rata-rata } & \multirow{2}{*}{ Kriteria } \\
\hline & & 1 & 2 & 3 & & & \\
\hline 1 & Keindahan Tampilan layar & 4 & 4 & 5 & 13 & $86,67 \%$ & Sangat Baik \\
\hline 2 & Keterbacaan teks & 4 & 5 & 5 & 14 & $93,33 \%$ & Sangat Baik \\
\hline 3 & $\begin{array}{l}\text { Kualitas gambar dan } \\
\text { animasi }\end{array}$ & 5 & 5 & 4 & 14 & $93,33 \%$ & Sangat Baik \\
\hline 4 & Komposisi warna & 4 & 4 & 5 & 13 & $86,67 \%$ & Sangat Baik \\
\hline 5 & Navigasi & 5 & 5 & 5 & 15 & $100 \%$ & Sangat Baik \\
\hline 6 & Daya dukung musik & 4 & 4 & 5 & 13 & $86,67 \%$ & Sangat Baik \\
\hline 7 & Interaksi & 5 & 4 & 4 & 13 & $86,67 \%$ & Sangat Baik \\
\hline & Rata-rata & 88,5 & 88,5 & 9,42 & 90,48 & $90,48 \%$ & Sangat Baik \\
\hline
\end{tabular}

\section{Data Hasil Uji Coba Tahap III Uji Coba Kelompok Kecil}

Uji coba kelompok kecil. Uji coba kelompok kecil dilakukan terhadap 9 orang siswa yang terdiri dari 3 siswa yang berprestasi tinggi, 3 siswa yang berprestasi sedang, dan 3 siswa yang berprestasi rendah. Data uji coba kelompok kecil ini dimaksudkan untuk mengetahui beberapa kelemahan/hambatan yang dihadapi ketika produk media pembelajaran interaktif digunakan. Uji coba kelompok kecil ini digunakan sebagai pengalaman awal sebelum produk diujicobakan ke lapangan. Hasil evaluasi pada aspek kualitas materi pembelajaran dapat dilihat pada Tabel 5.

Tabel 5. Skor Penilaian Media Pembelajaran Interaktif pada Pembelajaran Ekonomi Uji Coba Kelompok Kecil Aspek Kualitas Materi pembelajaran

\begin{tabular}{|c|c|c|c|c|c|c|c|c|}
\hline \multirow{2}{*}{ No } & \multirow{2}{*}{ Indikator Penilaian } & \multicolumn{5}{|c|}{ Skor } & \multirow{2}{*}{$\begin{array}{l}\text { Rata- } \\
\text { rata }\end{array}$} & \multirow{2}{*}{ Kriteria } \\
\hline & & 1 & 2 & 3 & 4 & 5 & & \\
\hline 1 & Kesesuaian materi & & & & 1 & 8 & $97,78 \%$ & Sangat Baik \\
\hline 2 & Kejelasan petunjuk belajar & & & & 2 & 7 & $95,56 \%$ & Sangat Baik \\
\hline 3 & $\begin{array}{l}\text { Kemudahan memahami kalimat } \\
\text { pada teks }\end{array}$ & & & & & 9 & $100 \%$ & Sangat Baik \\
\hline 4 & $\begin{array}{l}\text { Kemudahan memahami } \\
\text { pembelajaran }\end{array}$ & & & & & 9 & $100 \%$ & Sangat Baik \\
\hline 5 & Ketepatan urutan penyajian & & & & & 9 & $100 \%$ & Sangat Baik \\
\hline 6 & Kecukupan latihan & & & & 3 & 6 & $93,33 \%$ & Sangat Baik \\
\hline 7 & Kejelasan umpan balik & & & & 4 & 5 & $91,11 \%$ & Sangat Baik \\
\hline 8 & Bantuan belajar dengan program & & & & 2 & 7 & $95,56 \%$ & Sangat Baik \\
\hline
\end{tabular}




\begin{tabular}{|l|l|l|l|l|l|l|l|l|}
\hline \multirow{2}{*}{ No } & \multirow{2}{*}{ Indikator Penilaian } & \multicolumn{4}{|l|}{ Skor } & $\begin{array}{l}\text { Rata- } \\
\text { rata }\end{array}$ & Kriteria \\
\cline { 2 - 7 } & 1 & 2 & 3 & 4 & 5 & $\mathbf{9 6 , 6 7 \%}$ & Sangat Baik \\
\hline
\end{tabular}

Penilaian pada aspek kualitas materi pembelajaran untuk uji coba kelompok kecil yang tampak pada Tabel 5 menunjukkan bahwa secara keseluruhan dalam kriteria "Sangat Baik".

Tabel 6. Skor Penilaian Media Pembelajaran Interaktif pada Pembelajaran Ekonomi Uji Coba Kelompok Kecil Aspek Kualitas Teknis/Tampilan

\begin{tabular}{|l|l|l|l|l|l|l|l|l|}
\hline \multirow{2}{*}{ No } & \multirow{2}{*}{ Indikator Penilaian } & \multicolumn{3}{|l|}{ Skor } & \multirow{2}{*}{ Rata-rata } & \multirow{2}{*}{ Kriteria } \\
\cline { 3 - 7 } & & $\mathbf{1}$ & $\mathbf{2}$ & $\mathbf{3}$ & $\mathbf{4}$ & $\mathbf{5}$ & & \\
\hline 1 & Keindahan tampilan layar & & & & 5 & 4 & $88.89 \%$ & Sangat Baik \\
\hline 2 & Keterbacaan teks & & & & & 9 & $100 \%$ & Sangat Baik \\
\hline 3 & Kualitas gambar dan animasi & & & & 2 & 7 & $95.55 \%$ & Sangat Baik \\
\hline 4 & Komposisi warna & & & & 4 & 5 & $91.11 \%$ & Sangat Baik \\
\hline 5 & Navigasi & & & & & 9 & $100 \%$ & Sangat Baik \\
\hline 6 & Daya dukung musik & & & & 2 & 7 & $95.55 \%$ & Sangat Baik \\
\hline 7 & Interaksi & & & & & 9 & $100 \%$ & Sangat Baik \\
\hline
\end{tabular}

\section{Data Hasil Uji Coba Tahap IV Uji Coba Lapangan}

Uji coba lapangan. Uji coba lapangan dilakukan terhadap kelas X-2 yang teridiri dari 50 siswa dan penentuan kelas uji coba ini dilakukan secara acak dari 7 kelas $\mathrm{X}$ yang ada. Uji coba lapangan menghasilkan data-data yang nantinya akan mengukur kelayakan dari produk yang dikembangkan, serta untuk mengetahui bagaimana manfaat produk tersebut bagi pemakainya. Hasil evaluasi terhadap paket pembelajaran pada aspek kualitas materi pembelajaran dapat dilihat pada tabel pada Tabel 7.

Tabel 7. Skor Penilaian Media Pembelajaran Interaktif Pada Pembelajaran Ekonomi Uji Coba Lapangan Aspek Kualitas Materi Pembelajaran

\begin{tabular}{|l|l|l|l|l|l|l|l|l|}
\hline & & \multicolumn{3}{|l|}{ Skor } & & \\
\cline { 2 - 7 } No & Indikator Penilaian & 1 & 2 & 3 & 4 & 5 & Rata-rata & Kriteria \\
\hline 1 & Kesesuaian materi petunjuk & & & & 4 & 42 & $98 \%$ & Sangat Baik \\
\hline 2 & $\begin{array}{l}\text { Kejelasan } \\
\text { belajar }\end{array}$ & & & & 46 & $100 \%$ & Sangat Baik \\
\hline 3 & $\begin{array}{l}\text { Kemudahan memahami } \\
\text { kalimat pada teks }\end{array}$ & & & & 6 & 40 & $97,39 \%$ & Sangat Baik \\
\hline 4 & $\begin{array}{l}\text { Kemudahan memahami } \\
\text { pembelajaran }\end{array}$ & & & & 3 & 43 & $98,69 \%$ & Sangat Baik \\
\hline 5 & $\begin{array}{l}\text { Ketepatan } \\
\text { penyajian }\end{array}$ & & & & 4 & 42 & $91,30 \%$ & Sangat Baik \\
\hline 6 & Kecukupan latihan & & & & 6 & 40 & $98,26 \%$ & Sangat Baik \\
\hline 7 & Kejelasan umpan balik & & & & & 46 & $100 \%$ & Sangat Baik \\
\hline 8 & $\begin{array}{l}\text { Bantuan belajar dengan } \\
\text { program }\end{array}$ & & & 1 & 45 & 99,56 & Sangat Baik \\
\hline Rata-rata & & & & & $\mathbf{9 7 , 9 3 \%}$ & Sangat Baik \\
\hline
\end{tabular}

Tabel 7 menunjukkan hasil tanggapan siswa pada aspek kualitas materi pembelajaran untuk uji coba lapangan dan keseluruhannya dalam kriteria "Sangat Baik".

Hasil evaluasi terhadap paket pembelajaran pada aspek kualitas teknis/tampilan dapat dilihat pada tabel pada Tabel 8 . 
Tabel 8. Skor Penilaian Media Pembelajaran Interaktif Pada Pembelajaran Ekonomi Uji Coba Lapangan Aspek Kualitas Teknis/Tampilan

\begin{tabular}{|c|c|c|c|c|c|c|c|c|}
\hline \multirow[b]{2}{*}{ No } & \multirow[b]{2}{*}{ Indikator Penilaian } & \multicolumn{5}{|c|}{ Skor } & \multirow{2}{*}{$\begin{array}{l}\text { Rata- } \\
\text { rata }\end{array}$} & \multirow[b]{2}{*}{ Kriteria } \\
\hline & & 1 & 2 & 3 & 4 & 5 & & \\
\hline 1 & Keindahan tampilan layar & & & & 6 & 40 & $98 \%$ & Sangat Baik \\
\hline 2 & Keterbacaan teks & & & & & 46 & $100 \%$ & Sangat Baik \\
\hline 3 & Kualitas gambar dan animasi & & & & 4 & 42 & $98 \%$ & Sangat Baik \\
\hline 4 & Komposisi warna & & & & 5 & 41 & $98 \%$ & Sangat Baik \\
\hline 5 & Navigasi & & & & & 46 & $100 \%$ & Sangat Baik \\
\hline 6 & Daya dukung musik & & & & 3 & 43 & $99 \%$ & Sangat Baik \\
\hline 7 & Interaksi & & & & & 46 & $100 \%$ & Sangat Baik \\
\hline \multicolumn{7}{|c|}{ Rata-rata } & $99 \%$ & Sangat Baik \\
\hline
\end{tabular}

Adapun rangkuman persentase rata-rata hasil penilaian terhadap media pembelajaran interaktif pada pembelajaran Ekonomi oleh ahli materi, ahli desain pembelajaran, ahli rekayasa perangkat lunak, uji coba perorangan, uji coba kelompok kecil dan uji coba lapangan dapat dilihat pada tabel 9 berikut ini.

Tabel 9. Rangkuman Persentase Rata-Rata Hasil Penilaian Terhadap Media Pembelajaran Interaktif pada pembelajaran Ekonomi

\begin{tabular}{|l|l|l|l|}
\hline No & Responden & Persentase Rata-rata & Kriteria \\
\hline 1 & Ahli materi & $88,12 \%$ & Sangat Baik \\
\hline 2 & Ahli desain pembelajaran & $83,5 \%$ & Baik \\
\hline 3 & Ahli rekayasa perangkat lunak & $86,07 \%$ & Sangat Baik \\
\hline 4 & Siswa pada uji coba perorangan & $88,57 \%$ & Sangat Baik \\
\hline 5 & Siswa pada uji coba kelompok kecil & $96,27 \%$ & Sangat Baik \\
\hline 6 & Siswa pada uji coba lapangan & $98,46 \%$ & Sangat Baik \\
\hline & Rata-Rata & $\mathbf{9 0 \%}$ & Sangat Baik \\
\hline
\end{tabular}

\section{Pengujian Hipotesis}

Hipotesis yang diajukan pada penelitian ini adalah terdapat perbedaan yang signifikan antara hasil belajar siswa yang dibelajarkan dengan penggunaan media pembelajaran interaktif dan hasil belajar siswa yang dibelajarkan dengan penggunaan media pembelajaran Power Point. Rumus yang digunakan untuk uji hipotesis adalah uji-t. Dari hasil pengolahan data diperoleh $t_{\text {hitung }}$ sebesar 4,25 sedangkan tabel pada $\alpha=0,05$ dengan derajat kebebasan 94 adalah: 1,95. Karena thitung $(4,25)$ lebih besar dari $t_{\text {tabel }}(1,67)$ maka disimpulkan bahwa ada perbedaan hasil belajar yang diajarkan dengan menggunakan media pembelajaran interaktif dibanding dengan power point

Nilai keefektifan media pembelajaran intreaktif sebesar $84,83 \%$. Nilai keefektifan media pembelajaran power point sebesar $75,2 \%$. Hal ini berarti hasil belajar siswa yang dibelajarkan dengan dengan penggunaan media pembelajaran interaktif $(84,83 \%)$ lebih tinggi dari hasil belajar siswa yang dibelajarkan dengan peggunaan media pembelajaran Power point $(75,2 \%)$

\section{Pembahasan}

Produk pengembangan media pembelajaran interaktif pada Pembelajaran Ekonomi merupakan materi pembelajaran Ekonomi yang telah dikembangkan dengan memperhatikan aspek pembelajaran dan media sebagai prinsip desain pesan pembelajaran. Penelitan pengembangan produk yang dilakukan ini diarahkan untuk menghasilkan suatu produk berupa media pembelajaran interaktif pada pembelajaran Ekonomi untuk siswa SMA kelas $\mathrm{X}$ yang digunakan untuk meningkatkan proses pembelajaran maupun kompetensi siswa. Karena itu dalam prosesnya penelitian ini dilakukan dengan diawali studi pendahuluan, kemudian mendesain media pembelajaran, melakukan validasi produk dan melakukan revisi dan penyempurnaan berdasarkan analisis data validasi dari ahli materi, ahli desain pembelajaran dan ahli rekayasa perangkat lunak yang dilanjutkan 
dengan uji coba perorangan, uji coba kelompok kecil, dan uji coba lapangan sehingga dihasilkan media pembelajaran yang layak digunakan sesuai dengan karakteristik bidang studi dan siswa sebagai pengguna.

Manfaat yang diperoleh dari penggunaan media pembelajaran interaktif adalah konsep yang disajikan mudah dipelajari, dipahami dan sistematis. Media pembelajaran interaktif memberi kesempatan pada siswa untuk belajar sesuai dengan kecepatan masingmasing, belajar lebih cepat,mandiri dan tidak menimbulkan kebosanan karena dilengkapi dengan gambar-gambar dan animasi serta soal latihan yang bervariasi. Adanya pengulangan yang harus dilakukan saat jawaban salah menjadikan siswa lebih memahami materi. Media pembelajaran interaktif ini juga dapat digunakan sebagai alternatif media pembelajaran secara klasikal maupun individual.

Aspek yang direvisi dan disempurnakan berdasarkan analisis data dan uji coba serta masukan dari ahli materi, ahli desain pembelajaran, ahli rekayasa perangkat lunak dan siswa selaku pengguna media pembelajaran interaktif ini, bertujuan untuk menggali beberapa aspek yang lazim dalam proses pengembangan suatu produk. Variabel-variabel media pembelajaran memiliki nilai rata-rata sangat baik. Adapun variabel media pembelajaran yang dinilai meliputi kelayakan isi, penyajian, kebahasaan, pemprograman, dan kegrafikan.

Penggunaan media pembelajaran interaktif dalam pembelajaran Ekonomi memungkinkan siswa untuk berinteraksi langsung dan melakukan kontrol langsung pada sumber informasi, sehingga siswa dapat mengendalikan dan memperoleh apa yang menjadi kebutuhannya, misalnya membaca sumber-sumber untuk materi Permintaan dan Penawaran, dan harga keseimbangan pasar yang mana telah disediakan dalam media pembelajaran interaktif. Siswa juga dapat mengerjakan soal-soal latihan yang telah dilengkapi dengan balikan dan pembahasan sehingga siswa dapat mengetahui kesalahan yang telah dilakukan dalam mengerjakan soal latihan tersebut. Media pembelajaran interaktif juga dilengkapi dengan rangkuman yang dapat membantu siswa memperoleh ringkasan materi pelajaran yang dipaparkan.

Pembelajaran dengan media interaktif juga memungkinkan guru bebas melakukan interaksi dengan siswa sehingga pembelajaran tersebut bersifat interaktif yang membuat pembelajaran terfokus pada informasi yang sedang dipelajari. Hal ini berbeda dengan pembelajaran menggunakan media pembelajaran Power Point, siswa tidak berinteraksi langsung pada sumber informasi dan pembelajaran didominasi oleh guru yang menyajikan informasi secara linier atau satu arah. Hal ini terjadi karena pada media pembelajaran Power Point siswa mendapatkan sumber informasi hanya dari guru dan materimateri yang ada pada power point tanpa bisa memperoleh balikan dari soal-soal latihan yang dikerjakan. Pembelajaran dengan menggunakan media pembelajaran Power Point menempatkan guru sebagai pelaku yang aktif, sementara siswa relatif pasif hanya menerima dan mengikuti apa yang disampaikan guru. Guru menyampaikan materi secara terstruktur dengan harapan materi pelajaran yang disampaikan dapat dikuasai dengan baik dengan terfokus kepada kemampuan akademik.

Pembelajaran dengan menggunkan media pembelajaran interaktif memiliki tingkat keefektifan yang lebih tinggi dari pada penggunaan media power point. Hal ini dapat dilihat dari hasil nilai rata-rata Ekonomi siswa yang yang diajar dengan media pembelajaran interaktif yaitu sebesar $84,83 \%$, sedangkan hasil nilai rata-rata Ekonomi siswa yang yang diajar dengan media pembelajaran interaktif Power Point sebesar 75,2\%. Dari data ini membuktikan bahwa penggunaan media pembelajaran interaktif lebih baik dalam meningkatkan pengetahuan siswa dalam pembelajaran Ekonomi daripada penggunaan media pembelajaran Power Point

Walaupun dalam penelitian diperoleh data bahwa hasil belajar Ekonomi siswa lebih tinggi jika dibelajarkan dengan media pembelajaran interaktif daripada hasil pembelajaran Ekonomi siswa yang dibelajarkan dengan media pembelajaran Power Point, namun dalam pelaksanaannya kedua media pembelajaran ini telah mampu meningkatkan pemahaman dan hasil belajar Ekonomi siswa. Keefektifan penggunaan media pembelajaran interaktif adalah sebesar $84,83 \%$ dan Power Point sebesar 75,2\%.

\section{PENUTUP \\ Simpulan}

Hasil validasi dari ahli materi terhadap media pembelajaran interaktif pada 
pembelajaran ekonomi yang telah dikembangkan menunjukkan bahwa; (1) kualitas materi pembelajaran dinilai sangat baik; (2) kualitas strategi pembelajaran dinilai sangat baik, (3) kualitas sistem penyampaian pembelajaran dinilai sangat baik. Dengan demikian media pembelajaran interaktif pembelajaran yang dikembangkan dengan menggunakan program Macromedia Flash secara keseluruhan termasuk dalam kategori "Sangat Baik". Hasil validasi dari ahli desain pembelajaran terhadap media pembelajaran interaktif pada pembelajaran yang dikembangkan dengan menggunakan program Macromedia Flash menunjukkan bahwa; (1) kualitas desain pembelajaran dinilai sangat baik, (2) kualitas desain informasi dinilai sangat baik, (3) kualitas desain interaksi dinilai baik, (4) kualitas desain presentasi dinilai sangat baik. Berdasarkan hasil validasi tersebut disimpulkan bahwa media pembelajaran interaktif pada pembelajaran ekonomi yang dikembangkan termasuk dalam kriteria sangat baik sehingga dapat diterima dan layak digunakan dalam proses pembelajaran,. Hasil validasi dari ahli rekayasa perangkat lunak terhadap media pembelajaran interaktif pada pembelajaran ekonomi yang dikembangkan dengan program Macromedia Flash dinyatakan bahwa; (1) kualitas teknis/tampilan dinilai sangat baik, (2) pemprograman dinilai sangat baik. Dengan demikian media pembelajaran interaktif yang dikembangkan secara keseluruhan termasuk dalam kriteria sangat baik.

Menurut tanggapan siswa pada uji coba perorangan dinyatakan bahwa media pembelajaran interaktif yang dikembangkan dengan program Macromedia Flash termasuk kategori sangat baik dimana aspek materi pembelajaran dinilai dan kualitas teknis tampilan. Menurut tanggapan siswa pada uji coba kelompok kecil dinyatakan bahwa media pembelajaran interaktif yang dikembangkan dengan program Macromedia Flash termasuk kategori sangat baik dimana aspek materi pembelajaran dan kualitas teknis tampilan. Menurut tanggapan siswa pada uji coba lapangan dinyatakan bahwa media pembelajaran interaktif yang dikembangkan dengan program Macromedia Flash termasuk kategori sangat baik dimana aspek materi pembelajaran dan kualitas teknis tampilan.

$$
\text { Media pembelajaran yang }
$$
dikembangkan peneliti layak untuk digunakan sebagai media pembelajaran Ekonomi, karena memiliki nilai rata-rata yang lebih tinggi dari nilai median skala Likert. Media pembelajaran interaktif memiliki keefektifan lebih tinggi dari keefektifan media pembelajaran power point

Terhadap penggunaan media pembelajaran interaktif pada tes hasil belajar siswa menunjukkan bahwa hasil belajar siswa yang dibelajarkan dengan menggunakan media pembelajaran interaktif (kelas eksperimen) lebih tinggi dari hasil belajar siswa yang dibelajarkan dengan menggunakan media pembelajaran power point (kelas kontrol). Dengan demikian disimpulkan bahwa terdapat perbedaan yang signifikan antara hasil belajar siswa yang dibelajarkan dengan menggunakan media pembelajaran inetraktif dengan hasil belajar siswa yang dibelajarkan dengan media pembelajaran power point.

\section{Saran}

Berdasarkan hasil temuan yang telah diuraikan pada Simpulan serta implikasi hasil penelitian, berikut ini diajukan beberapa saran yaitu:

1. Penggunaan media pembelajaran perlu diadakan pengontrolan terhadap guru yang menggunakan media pembelajaran. Guru harus memiliki profesionalitas yang sama, latar belakang pendidikan yang sama serta penampilan yang hampir sama dalam menggunakan media pembelajaran. Jika digunakan media pembelajaran yang baru perlu adanya pelatihan terhadap guru atas penggunaan media pembelajaran sehingga mempermudah guru dalam menyampaian tahapan-tahapan dalam pembelajaran.

2. Perlu diadakannya kesiapan fasilitas pendukung dalam menggunakan media pembelajaran interaktif, misalnya komputer. Dalam hal kelengkapan fasilitas seperti komputer tidak semua semua sekolah pasti memilikinya sehingga perlu digunakan media pembelajaran yang sesuai dengan kebutuhan sekolah.

3. Kepada peneliti selanjutya diharapkan pembelajaran dengan menggunakan media pembelajaran interaktif menharuskan guru menyesuaikan isi materi dan penggunaan waktu jam pelajaran, sehingga dapat mempengaruhi hasil belajar siswa khususnya pada hasil belajar ekonomi.

4. Pembelajaran interaktif sangat penting dalam kegiatan pembelajaran. Untuk menambah variasi media pembelajaran 
sebaiknya menggunakan software yang baru atau mengembangkan media interaktif yang telah dikembangkan.

\section{DAFTAR PUSTAKA}

Anderson, dkk. 2001. A Taxonomy For Learning, Teacher \&Assessing. New York. Longman,Inc.

AECT. 1977. Definisi Teknologi Pendidikan (satuan tugas definisi \& terminologi AECT). Jakarta: Rajawali.

Arikunto, S. 2009. Dasar-Dasar Evaluasi Pendidikan, ediasi Revisi Jakarta : Bumi Aksara.

Arsyad, A. 2010. Media pembelajaran. Jakarta : Raja Grafindo Persada.

Arum, dkk. 2012. Rancangan Bangun Sistem Pembelajaran Teses Berbasis Macromedia Flash 8. Jurnal : Informatika dan teknik Elektro Terapan. 1(1) 1

BNSP, 2006, Standar Isi Mata Pelajaran Ekonomi SMA, Jakarta : Purkur

Borg, W. \&V Gall, M.D. 1983. Educational Research. An Introduction (4 $\left.{ }^{\text {nd }} \mathrm{ed}\right)$. New York \& London: Longman.

Case \& Fair. 2006. Prinsip-prinsip ekonomi julid I. Jakarta : Erlangga

Cheng, G. 2009. Using game making pedagogy to facilitate student learning of interactive multimedia. Australia : Australasian Journal of Educational Technology

Danim, Sudarwan. 2010. Media Komunikasi pendidikan. Jakarta : Bumi Aksara

Dick, W. dan Carey, L. 2005. The Systematic Design of Instruction. United States of America: Scott Foresman and Company.

Emzir, 2012. Metodologi Penelitian Pendidikan. Jakarta : Raja Grafindo Persada

Hamid,A. 2009. Teori Belajar dan Pembelajaran. Bandung : Alfa beta

Heinich, Robert, et. Al. 1996 Instructional Media and Technologies for Learning $\left(5^{\text {th }} e d\right)$. New Jersey : A Simon \& Schuster Company Engelewood Cliffs.

Maduin, Madcons. 2009. Panduan Lengkap Adoebe Flash CS4 Profesional. Yogyakarta: Andi Offset

Mankiw, dkk. 2013. Pengantar Ekonomi Mikro. Jakarta : Salemba emapat
Miarso, Yusufhadi. 2009. Menyemai Benih Teknologi Pendidikan (Ed. 1) Cet. Ke-4. Jakarta: Kencana

Purwanto, Ngalim. 2009. Prinsip-Prinsip dan Teknik Evaluasi Pengajaran Cet. Ke-15. Bandung: Remaja Rosdakarya

Rahman, dkk. 2008. Optimalisasi Macromedia Flash untuk mendukung Pembelajaran Berbasis Komputer Program Studi Ilmu Komputer FPMIFA UPI. Jurnal Pendidikan Ilmu Komputer FPMIFA UPI. 1(1) 1

Reigeluth, C.M. 1983. Instructional Design Theories and Model. London: Lawrence Erlbaum Associates Publisher

Richey, R. 1986. The Theoretical and Conceptual Bases of Instructional Design. New York. Nichols Publishing Company

Rusman, dkk. 2012. Pembelajaran berbasis teknologi dan informasi dan komunikasi. Jakarta : Rajawali.

Sadiman, A. dkk. 2003. Media Pendidikan, Pengertian, Pengembangan dan Pemanfaatannya . Jakarta : Pustekkom Dikbud.

Sagala, S. 2011. Konsep dan Makna Pembelajaran. Bandung : Alfa beta

Siagian, S, Lingin.(2012) Jurnal Teknologi Pendidikan. Pengembangan Media Pembelajaran Interaktif pada Mata Pelajaran Geografi.

Smaldino, E. S., dkk. 2008. Instrucional Technology and Media For Learning. New Jersey: Upper Saddle River.

Soeharno. 2006. Teori Ekonomi Ekonomi. Yogyakarta : Andi Offset

Spark, S. 2005. Macromedia Flash Tutorial. Macromedia. Inc. San Fransisco

Sudjana. 2005. Metoda Statistika (Ed. Ke-6) Cet. Ke-3. Bandung: Tarsito Sinar Baru Offset.

Sumiati. 2008. Metode Pembelajaran. Bandung. Wacana Prima

Sudijono, Anas. 2008. Pengantar Statistik Pendidikan. Jakarta. Raja Grafindo Persada

Sugiyono. 2008. Metode Penelitian Kuantitatif, Kualitatif dan $R \quad \& \quad D$ Cet. $\mathrm{Ke}-4$. Bandung. Alfabeta

Surya, Mohammad. 2003. Psikologi Pembelajaran dan Pengajaran. Jakarta: Pusataka Bani Quraisy

Sutopo, A. 2003. Multimedia Interaktif Dengan Flash. Yogyakarta: Graha Ilmu. 
Viajayani, dkk. 2013. Pengembangan Media Pembelajaran Fisika menggunakan Macromedia flash pro 8 pada pokok bahasan suhu dan kalor. Jurnal Pendidikan Fisika. 1(1) 145

Warsita, B. 2002. Teknologi Pembelajaran Landasan \& Aplikasinya. Jakarta: Rineka Cipta
Weda, Made. 2013. Strategi Pembelajaran Inovatif Kontemporer. Jakarta : Bumi Aksara

Zaman, dkk. 2012. Pengembangan Multimedia Pembelajaran Interaktif Menggunakan Macromedia Flash Professional pada Pembelajaran Fisika. Indonesian Jornal Of Curriculum and Educational Technology Studies. Jurnal. 1(1)1 